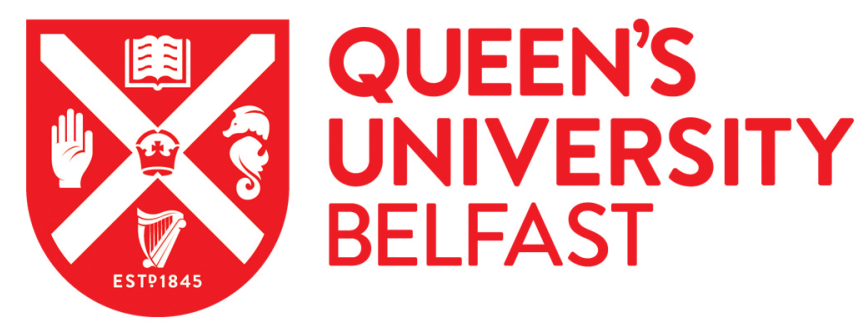

\title{
Basic lonic Liquid Gels for Catalysis: Application to the Hydrogen Borrowing Mediated Dehydration of 1,3-Propanediol.
}

\author{
Bothwell, K. M., Lorenzini, F., Mathers, E., Marr, P. C., \& Marr, A. C. (2019). Basic lonic Liquid Gels for \\ Catalysis: Application to the Hydrogen Borrowing Mediated Dehydration of 1,3-Propanediol. ACS Sustainable \\ Chemistry \& Engineering, 7(2), 2686-2690. https://doi.org/10.1021/acssuschemeng.8b05762
}

Published in:

ACS Sustainable Chemistry \& Engineering

\section{Document Version:}

Peer reviewed version

Queen's University Belfast - Research Portal:

Link to publication record in Queen's University Belfast Research Portal

Publisher rights

Copyright $\odot 2018$ American Chemical Society. This work is made available online in accordance with the publisher's policies. Please refer to any applicable terms of use of the publisher.

\section{General rights}

Copyright for the publications made accessible via the Queen's University Belfast Research Portal is retained by the author(s) and / or other copyright owners and it is a condition of accessing these publications that users recognise and abide by the legal requirements associated with these rights.

Take down policy

The Research Portal is Queen's institutional repository that provides access to Queen's research output. Every effort has been made to ensure that content in the Research Portal does not infringe any person's rights, or applicable UK laws. If you discover content in the Research Portal that you believe breaches copyright or violates any law, please contact openaccess@qub.ac.uk. 


\title{
Basic Ionic Liquid Gels for Catalysis: Application to the Hydrogen Borrowing Mediated Dehydration of 1,3-Propanediol.
}

\author{
Kyra M. Bothwell, Fabio Lorenzini, Ellen Mathers, Patricia C. Marr* and Andrew C. \\ Marr* \\ ${ }^{a}$ School of Chemistry and Chemical Engineering, Queen's University of Belfast, \\ David Keir Building, Stranmillis Road, Belfast, BT9 5AG, UK. \\ *E-mail:p.marr@qub.ac.uk,*E-mail:a.marr@qub.ac.uk.
}

\section{Dedication}

This article is dedicated to our friend, the unique and brilliant Kenneth Seddon. His encouragement and enthusiasm are sorely missed.

\begin{abstract}
The application of basic ionic liquid gels (BILGs) as recyclable promoters of hydrogen borrowing chemistry was investigated. The hydrogen transfer initiated dehydration of 1,3-propanediol to propanal was catalysed by a [Cp* $\left.\operatorname{IrCl}_{2}(\mathrm{NHC})\right]$ complex promoted by BILGs containing $\left[\mathrm{P}_{6,6,6,14}\right][\mathrm{OH}]$. Gels comprising a mixture of basic and hydrophobic ionic liquids gave the best results. The reaction proceeded in the ionic liquid $\left[\mathrm{C}_{2} \mathrm{mmim}\right]\left[\mathrm{NTf}_{2}\right]$ enabling the continuous removal of propanal under reduced pressure. Tuning of the composition of the BILG led to a catalytic system that exhibited excellent conversion, selectivity and good recyclability.
\end{abstract}

Keywords: Ionic Liquid, Gel, Ionogel, Hydrogen Borrowing, 1,3-propanediol

\section{Introduction}

Hydrogen borrowing / hydrogen transfer methodologies have proven to be extremely powerful tools in sustainable chemical synthesis. In these reactions a catalyst is added that removes hydrogen from a hydrogen donor and transfers it to another molecule, or part of the same molecule. In 1981 Grigg and co-workers at Queen's University Belfast applied their platinum group metal catalysed hydrogen transfer reaction to affect the alkylation of amines. ${ }^{1}$ Early work on Ruthenium catalysts was also performed by Watanabe and co-workers. ${ }^{2}$

40 years later a myriad of synthetic protocols have been developed that depend upon transition metal mediated hydrogen transfer, and many of them build directly on the 
early work in the 1970 's and early 80 s. In the $21^{\text {st }}$ century hydrogen transfer methods that move hydrogen from one organic functionality to another via a catalyst have been rebranded as 'hydrogen borrowing'. 3

Our investigations of hydrogen borrowing mediated alkylation of amines began with an endeavour to utilise waste glycerol from biodiesel production, in collaboration with Stephens and Rebros. ${ }^{4}$ The whole cell biocatalytic digestion of glycerol with Clostridium Butyricum leads to the formation of usable quantities of 1,3-propanediol (1,3-PDO), an important bio-renewable platform chemical, and currently prepared on the large industrial scale by the fermentation of sugars. ${ }^{5,6}$

Downstream chemical transformation of aliphatic alcohols such as 1,3-PDO can be challenging, and we investigated the application of modern homogeneous catalytic methods and solvent technologies. Hydrogen borrowing $N$-alkylation methods have a wide applicability for bio-derived alcohols and mono and di-amination of 1,3-PDO, initiated by $\left[\mathrm{Cp}^{*} \mathrm{IrCl}_{2}(\mathrm{NHC})\right]\left(\mathrm{Cp}^{*}=\right.$ pentamethylcyclopentadienyl; $\mathrm{NHC}=$ carbene ligand) pre-catalysts was successful using aniline. ${ }^{4,7,8}$ An unexpected side reaction, which occurred in parallel to amination, was the partial dehydration of 1,3-PDO, this reaction was particularly prevalent in the ionic liquid methyl-trioctylammonium bis(trifluoromethylsulfonyl)imide $\left.\left[\mathrm{N}_{1,8,8,8}\right] \mathrm{NTf}_{2}\right]$, and could be performed in the presence of water, and in air. ${ }^{8}$

Hydrogen transfer initiated dehydration (HTID) could be performed in the absence of the amine to yield a mixture of C3 and C6 aldehydes and alcohols (Figure 1). The aldol and hydrogenation reactions to form the $\mathrm{C} 6$ and alcohol products respectively could be suppressed by performing the reaction under a mild vacuum. ${ }^{9}$ This facilitated the attainment of $84 \%$ crude isolated yield and a selectivity to propanal of $86 \%$. The $\operatorname{Ir}(\mathrm{III})\left[\mathrm{Cp}^{*} \mathrm{IrCl}_{2}(\mathrm{NHC})\right]$ catalyst $\mathbf{C 1}$ (Figure 2) employed could be recycled with good retention of activity and selectivity, and exhibited excellent air and water stability; however the base $\left(\mathrm{K}_{2} \mathrm{CO}_{3}\right)$ was found to require replenishment in order to achieve satisfactory recycling of the catalytic system.

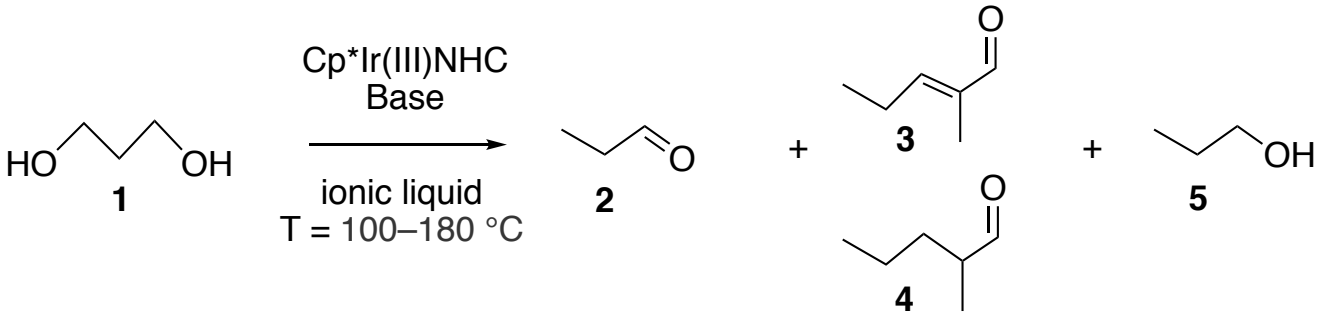

Figure 1. Hydrogen Transfer Initiated Dehydration of 1,3-propanediol.

Subsequent optimisation of the solvent, conditions and catalyst led to the attainment of a quantitative crude isolated yield with $87 \%$ selectivity to propanal. This reaction was performed using a fluorinated version of the benzyl catalyst (C2, Figure 2) in 1ethyl-2,3-dimethyl-imidazolium- $N, N$-bistriflimide $\left[\mathrm{C}_{2}\right.$ mmim $]\left[\mathrm{NTf}_{2}\right] .{ }^{10}$ 


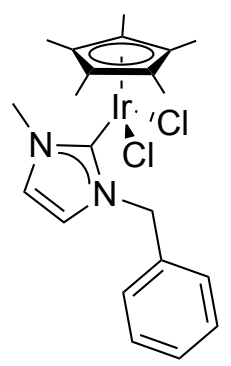

C1

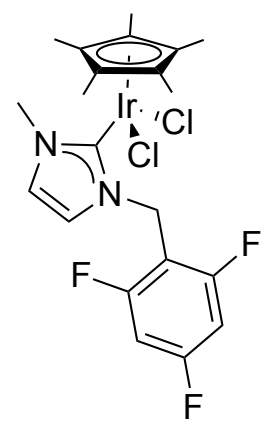

$\mathrm{C2}$

Figure 2. Hydrogen Borrowing Ir(III) Catalysts C1 and C2.

Despite the recyclability of the catalyst and facile isolation of the product, the poor stability of the base, and therefore requirement to periodically add more base, prevents HTID chemistry from being classed truly 'green'. The resultant build-up of salts will inevitably change the process conditions and lead to the frequent requirement for reprocessing of the catalyst and ionic liquid. We therefore turned our attention to the discovery and invention of a more stable base that could be recycled under HTID conditions, and to this end combined this investigation with another ongoing research project, the preparation of basic ionic liquid gels (BILGs). Ionic liquid gels for application in sustainable chemistry have been receiving increasing attention. ${ }^{11}$ Notable applications can be envisaged in energy and catalytic applications. The gel state provides heterogenized separations, but reactivity occurs in a liquid environment, entrapped within the matrix of the gel, and is therefore closely analogous to homogeneous catalysis.

One of the oldest and most successful applications of ionic liquids to chemistry is the catalytic application of acidic ILs. Two companies have declared processes in this class, China National Petroleum Corp. company Petrochina, and, more recently Chevron, with their ISOALKYL ${ }^{\mathrm{TM}}$ Process. In these processes ionic liquids with acidic anions replace conventional homogeneous acids such as $\mathrm{H}_{2} \mathrm{SO}_{4}$ and $\mathrm{HF}$ as catalysts in alkylation reactions. This results in greener processes with less waste, easier catalyst recycle and less danger, exactly as proposed by Earle and Seddon pre$2000 .{ }^{12}$ Acidic ionic liquid catalysts can be heterogenized by employing gel technologies. Brønsted acidic ionic liquids entrapped within silica gels operate as solid catalysts that are simple to separate from the product mixture. ${ }^{13}$

The potential use of Brønsted basic ionic liquids to replace conventional basic catalysts has interested many research groups. ${ }^{14,15,16,17,18,19}$ Unfortunately basic ionic liquids are found to be prone to side reactions that decompose the ions over mid to long periods. Careful molecular design can overcome this problem, but the resultant ILs tend to be expensive and require multistep syntheses. An alternative method is to prepare a binary mixture of a basic ionic liquid containing hydrophobic ions. We found this approach worked well for alkoxide ionic liquids of pyrrole applied to catalytic Knoevenagel and Aldol reactions. ${ }^{20}$ Another approach is to prepare an ionic liquid gel. Phosphonium hydroxide ionic liquids have been found to autocatalyse the formation of silica and titania BILGs. ${ }^{21}$ The application of the IL slowed down the basic sol-gel process and led to the formation of good transparent gels that could be 
coated. In addition entrapment of $\left[\mathrm{P}_{6,6,6,14}\right][\mathrm{OH}]$ was found to significantly stabilise the cation compared to the liquid phase.

Inspired by our success applying autocatalytic acidic ionic liquid gels in dehydration reactions, ${ }^{13}$ we decided to attempt hydrogen borrowing initiated dehydration in the presence of BILGs.

\section{Results and discussion}

\section{HTID Catalytic Conditions}

The catalysts $\mathbf{C 1}$ and $\mathbf{C 2}$ (Figure 2) have been shown to be active for the HTID of 1,3PDO to aldehydes in ionic liquids (Figure 1). The application of an $\operatorname{Ir}(\mathrm{III})$ catalysts affords a high level of air and moisture stability to the catalyst. Operating the reaction in an ionic liquid enables the product to be distilled from the mixture during the reaction on application of a vacuum (350 mbar). Such conditions are easily achievable in industry. Some typical previous results are summarised in Table 1. Under these reactions the bases tested, including $\mathrm{K}_{2} \mathrm{CO}_{3}$ and $\mathrm{KOH}$, were gradually consumed. In imidazolium IL $\left[\mathrm{C}_{2} \mathrm{mmim}\right]\left[\mathrm{NTf}_{2}\right]$ at $150{ }^{\circ} \mathrm{C} \mathbf{C 2}^{10}$ was found to have a better tolerance for $\mathrm{KOH}$ than $\mathbf{C 1} .^{9}$ Trifluorinated benzyl Cp* $\mathrm{Ir}(\mathrm{III}) \mathrm{NHC}$ complex $\mathbf{C 2}$ was chosen as the catalyst for the HTID reaction of 1,3-propanediol using BILGs.

Table 1. Catalytic performance of $\mathrm{C} 1$ and $\mathrm{C} 2$ in the HTID of 1,3-PDO. ${ }^{\mathrm{a}, 9,10}$

\begin{tabular}{ccccccccc}
\hline Entry & Catalyst & {$[\mathbf{1 , 3 - P D O}]:[\mathbf{I r}]$} & $\mathbf{B a s e}$ & $\mathbf{\%}$ Yield $^{\mathbf{b}}$ & $\mathbf{2}$ & $\mathbf{3}$ & $\mathbf{4}$ & $\mathbf{5}$ \\
\hline 1 & $\mathbf{C 1}$ & 75.1 & $\mathrm{~K}_{2} \mathrm{CO}_{3}$ & 78 & 73.0 & 10.1 & 8.6 & 8.3 \\
2 & $\mathbf{C 1}$ & 219.7 & $\mathrm{~K}_{2} \mathrm{CO}_{3}$ & 70 & 72.7 & 12.5 & 6.1 & 8.6 \\
3 & $\mathbf{C 1}$ & 226.1 & $\mathrm{KOH}$ & 54 & 85.2 & 5.9 & 1.4 & 7.5 \\
4 & $\mathbf{C 2}$ & 80.3 & $\mathrm{~K}_{2} \mathrm{CO}_{3}$ & 85 & 83.6 & 4.3 & 0.0 & 12.1 \\
5 & $\mathbf{C 2}$ & 212.4 & $\mathrm{~K}_{2} \mathrm{CO}_{3}$ & 70 & 72.7 & 8.8 & 1.2 & 17.3 \\
6 & $\mathbf{C 2}$ & 208.8 & $\mathrm{KOH}$ & 85 & 88.8 & 1.5 & 0.0 & 9.7
\end{tabular}

$\boldsymbol{a}$ Reactions performed in $\left[\mathrm{C}_{2} \mathrm{mmim}\right]\left[\mathrm{NTf}_{2}\right], \mathrm{T}=150^{\circ} \mathrm{C}, \mathrm{P}=0.35$ bar, with reaction time: $6 \mathrm{~h}$, stirring speed 1000 RPM. $\boldsymbol{b}$ Crude isolated yield.

\section{BILG Synthesis}

The first BILGs tested were based on $\left[\mathrm{P}_{6,6,6,14}\right][\mathrm{OH}]$ entrapped in silica, as reported previously. ${ }^{21}$ These can be prepared by the simple addition of tetraethoxysilane (TEOS) to the ionic liquid; the process of gel formation is autocatalytic. 
$\left[\mathrm{P}_{6,6,6,14}\right][\mathrm{OH}]$ silica gels were found to give unreliable catalytic results in hydrogen borrowing experiments. In order to improve the durability of the BILGs a gel based on a mixed IL system was attempted. In order to do this an additional IL was added to the preparation. In our experience the silica gels of hydrophobic $\mathrm{C}_{4}$ imidazolium [ $\left.\mathrm{NTf}_{2}\right]$ ILs exhibit good stability and so $\left[\mathrm{C}_{4} \mathrm{mmim}\right]\left[\mathrm{NTf}_{2}\right]$ was chosen as the cosolvent. Maintaining a 1:1 ratio of IL and TEOS by volume, the ratio of the ionic liquids was varied (Table 2). Three gels were prepared containing $\left[\mathrm{C}_{4} \mathrm{mmim}\right]\left[\mathrm{NTf}_{2}\right]:\left[\mathrm{P}_{6,6,6,14}\right][\mathrm{OH}]$ of 3:1 (G1), 1:1 (G2) and 1:3(G3). The gels were aged for 4 weeks and extracted with ethanol to remove any IL that was not entrapped. The resultant gel was tested for leaching in toluene under reflux for 6 hours. No leaching was detected by ${ }^{31} \mathrm{P}$ NMR nor by ${ }^{19} \mathrm{~F}$ NMR.

Table 2. Silica BILGs containing $\left[\mathrm{P}_{66614}\right][\mathrm{OH}]$ and $\left[\mathrm{C}_{4} \mathrm{mmim}\right]\left[\mathrm{NTf}_{2}\right]$.

\begin{tabular}{|c|c|c|c|c|c|c|}
\hline Entry & Gel & {$\left[\mathrm{C}_{2}\right.$ mmim $]\left[\mathrm{NTf}_{2}\right]^{\mathrm{a}}$} & {$\left[\mathrm{P}_{6,6,6,6,14}\right][\mathrm{OH}]^{\mathrm{a}}$} & TGA $/{ }^{\circ} \mathrm{C}$ & $\begin{array}{c}\text { BET surface } \\
\text { area/ } \mathbf{m}^{2} / g\end{array}$ & $\begin{array}{c}\text { BET pore } \\
\text { size/ nm }\end{array}$ \\
\hline 1 & G1 & 0.75 & 0.25 & 274 & 140.9 & $8.1-10.5$ \\
\hline 2 & G2 & 0.50 & 0.50 & 253 & 224.7 & 7.3-8.9 \\
\hline 3 & G3 & 0.25 & 0.75 & 241 & 222.1 & $10.8-14.3$ \\
\hline
\end{tabular}

$\boldsymbol{a}$ Ratio (by volume) relative to TEOS.

The surface area of the material was found to increase as the proportion of phosphonium IL was increased from G1 to G2. G3 was found to have the highest average pore size, and similar surface area to G2. The thermal stability reduced slightly as the proportion of $\left[\mathrm{P}_{6,6,6,14}\right][\mathrm{OH}]$ was increased, this is expected as the thermal stability of imidazolium [ $\mathrm{NTf}_{2}$ ] ILs far exceeds that of phosphonium hydroxides.

\section{Hydrogen Borrowing in the presence of a BILG}

The BILGS G1-3 were tested in the HTID of 1,3-PDO catalysed by C2. Initial studies were carried out to optimise the quantity of gel required to promote dehydration. The results are reported in Table S1. Efficient HTID relies on the correct concentration of base, with too much or too little significantly reducing performance. The optimum quantities of gel required were $0.7 \mathrm{~g}$ from $\mathbf{G 1}, 0.4 \mathrm{~g}$ for $\mathbf{G 2}$ and $0.6 \mathrm{~g}$ for $\mathbf{G 3}$. The catalytic results obtained for the three gel systems under these conditions are summarised in Table 3.

Table 3. Catalytic performance of gels G1-3 in the C2 catalysed HTID of 1,3PDO. ${ }^{a}$ 


\begin{tabular}{ccccccc}
\hline Entry & Base & ${\text { \% } \text { Yield }^{\mathbf{b}}}$ & $\mathbf{2}$ & $\mathbf{3}$ & $\mathbf{4}$ & $\mathbf{5}$ \\
\hline 1 & $\mathbf{G 1}$ & 80 & 88.7 & 3.1 & 0 & 8.3 \\
2 & $\mathbf{G 2}$ & $>99$ & 81.9 & 2.8 & 0 & 15.3 \\
3 & $\mathbf{G 3}$ & 87 & 90.3 & 3.1 & 0 & 6.5
\end{tabular}

$\boldsymbol{a}$ Reactions performed in [ $\left.\mathrm{C}_{2} \mathrm{mmim}\right]\left[\mathrm{NTf}_{2}\right], \mathrm{T}=150{ }^{\circ} \mathrm{C}, \mathrm{P}=0.35$ bar, [1,3-PDO]:[Ir] $=75$, with reaction time: $6 \mathrm{~h}$, stirring speed 1000 RPM. $\boldsymbol{b}$ Crude isolated yield.

The performances of the three BILG promoted systems were highly competitive, rivalling the best results obtained for HTID of 1,3-PDO observed thus far. G1 afforded $80 \%$ yield and $89 \%$ selectivity to propanal (2), G2 over 99\% yield and $82 \%$ 2 and $\mathbf{G 3} 87 \%$ yield and 90\% 2. These results are very similar to optimised $\mathrm{KOH}$ and $\mathrm{K}_{2} \mathrm{CO}_{3}$ systems. ${ }^{9,10}$ Thus far we have been unable to achieve similar catalytic performances using homogeneous basic ionic liquids nor fully heterogenized systems containing a co-entrapped hydrogen borrowing catalyst and basic ionic liquid. The high activity of the catalytic system employing $\mathbf{G 2}$ correlates with the high relative surface area of this BILG. The lower pore size of $\mathbf{G 2}$ was not detrimental to the activity as a base in HTID.

Adopting BILG promoters is envisaged having a number of advantages, including increased safety of use and ease of handling. Important amongst these advantages is reusability, which will reduce costs and material consumption, and therefore the BILGs were tested in catalyst recycling experiments.

\section{Recycling the Ir(III) BILG system}

All three BILG systems exhibited better performance than $\mathrm{KOH}$ and $\mathrm{K}_{2} \mathrm{CO}_{3}$ in recycling experiments. For the conventional bases an additional aliquot of $\mathrm{KOH}$ or $\mathrm{K}_{2} \mathrm{CO}_{3}$ was required for each catalytic run, leading to a build-up of waste salts. ${ }^{9,10}$ The BILG promoters G1-3 could all be reused. A comparison of five recycles of HTID catalyst $\mathbf{C 2}$ in [ $\left.\mathrm{C}_{2} \mathrm{mmim}\right]\left[\mathrm{NTf}_{2}\right]$ promoted by G1, G2 and G3 (Tables S2-4, Figure 3) revealed that there was a significant drop in the performance of the catalyst over five runs for $\mathbf{G 1}$ and $\mathbf{G 2}$. In contrast the performance of $\mathbf{C 2}$ promoted by $\mathbf{G 3}$ was consistent over five runs in activity and selectivity. The 1:3 ratio of $\left[\mathrm{C}_{4} \mathrm{mmim}\right]\left[\mathrm{NTf}_{2}\right]:\left[\mathrm{P}_{6,6,6,14}\right][\mathrm{OH}]$ provided the best compromise of basicity, stability and affinity for the silica matrix. This formulation also afforded the largest pore size (Table 1), which will assist diffusion and resist pore blockage.

The stability of binary mixtures of basic and hydrophobic ionic liquids was demonstrated previously for pyrrole alkoxide ionic liquids. ${ }^{20}$ We suggest that hydrophobic ions protect the cation from decomposition pathways, for example the attack of hydroxide arising from absorbed moisture. The reasons behind the success of $\mathbf{G 3}$ as a recyclable basic promoter of HTID are more complex, as there are many factors involved that cannot be altered independently, for example porosity, surface area, basicity and ionic liquid stability. Base activity correlates with surface area, and it is likely that the reaction occurs most efficiently near the surface of the gel. We have observed lower activities in gels incorporating hydrogen borrowing catalysts entrapped within. The lower activities of these Iridium containing basic ionic liquid 
gels may arise from a combination of longer diffusion pathways for the substrate, and non-optimal basicity within the gel.

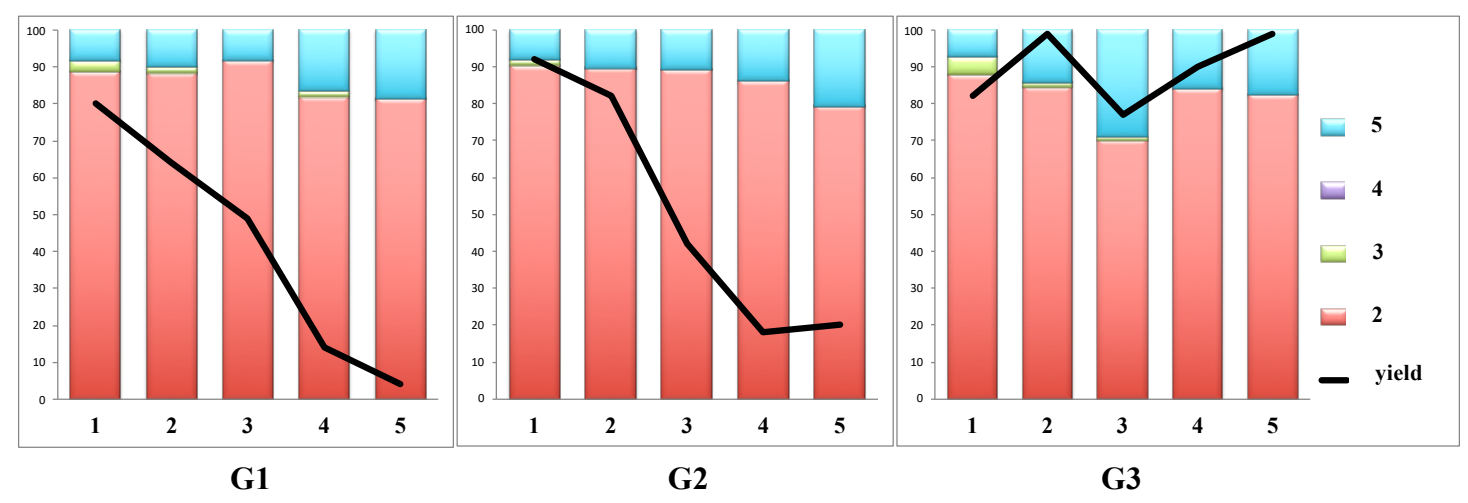

Figure 3. Recycling of HTID promoted by gels G1, G2 and G3.

\section{Experimental}

\section{Material and equipment}

TEOS ( $\geq 97 \%$, TCI UK), 1,3-Propanediol (98\% $w$, Aldrich), propanal (97\% $w$, Aldrich), 2-methyl-2-pentenal (97\% w, Aldrich), 2-methyl-pentanal ( $>95.0 \% \mathrm{w}, \mathrm{TCI})$, propanol (97\% $w$, Sigma-Aldrich), methanol ( $\geq 99.9 \%$, CHROMASOLV, for HPLC, Sigma- Aldrich), $\mathrm{CDCl}_{3}$ (99\% w, Aldrich), Amberlite IRN78 hydroxide form (Sigma Aldrich), $\left[\mathrm{P}_{6,6,6,14]}[\mathrm{Cl}]\right.$ (97.7\%, CYPHOS IL 101), $\mathrm{AgNO}_{3}$ (99\%, Sigma Aldrich), Nitric acid ( $\geq 90 \%$, Sigma Aldrich), KOH ( $85 \%$ w, Riedel-de Haën), 1,2dimethylimidizole (98\%, Sigma Aldrich), 1-methylimidazole (99\%, Sigma Aldrich), 1-bromoethane (98\%, Sigma Aldrich), 1-bromobutane (98\%, Sigma Aldrich), 1bromooctane (99\%, Sigma Aldrich), Lithium bistriflimide (HQ115, 3M), Silver Oxide (99\%, Sigma Aldrich), decelite (speed plus, diatomaceous filter-aid, Acros Organics), 1-benzyl-3- methylimidazolium bromide (97\%, Sigma Aldrich), $\left[\mathrm{Cp}^{*} \mathrm{IrCl}_{2}\right]_{2}(96 \%$, Sigma Aldrich), 2,4,6-trifluorobenzyl bromide (97\%, Fluorochem), Pentafluorobenzyl bromide (99\%, Fluorochem) were used as received.

${ }^{1} \mathrm{H}$ NMR and ${ }^{31} \mathrm{P}$ NMR spectra were measured on a Bruker Avance III HD $300 \mathrm{MHz}$. The chemical shifts are reported in ppm related to TMS. Signal multiplicities are reported as singlet (s), doublet (d), triplet (t), and multiplet (m). GC/MS spectroscopic data were collected on a MassHunter Workstation Software - Qualitative Analysis Version B.06.00 - Build 6.0.663.10 - Service Pack 1 - (C) Agilent Technologies, Inc. 2012. GC/MS Column: Agilent Technologies, Inc.; 19091S-433UI; HP-5MS UI; 30 m X $0.250 \mathrm{~mm}$; 0.25 Micron; -60 to 325/350C; SN: USE137316H. GC/MS spectroscopic data were processed on MassHunter Data Analysis -

MassHunter GC/MS Acquisition B.07.01.1805 - 12-Mar-2014 - (C) 1989-2014 Agilent 184

Technologies. Thermogravimetric analysis (TGA) was carried out using a TGA Q5000 IR thermogravimetric analysis. The samples were heated in $\mathrm{N}_{2}$ gas with a 
balance purge flow of $25 \mathrm{~mL} / \mathrm{min}$ and a sample purge flow of $10 \mathrm{~mL} / \mathrm{min}$, with a heating rate of $10^{\circ} \mathrm{C}$ per minute within a temperature range of $30^{\circ} \mathrm{C}$ to $600{ }^{\circ} \mathrm{C}$. Brunauer-Emmett- Teller theory (BET) was used to determine the surface area and porosity; measured with a Tristar II 3020 instrument and using $\mathrm{N}_{2}$ as the adsorption gas.

\section{Synthesis}

$\mathbf{C 1}$ and $\mathbf{C 2}$ were prepared according to literature methods..$^{9,10}$

$\left[\mathrm{C}_{2} \mathrm{mmim}\right]\left[\mathrm{NTf}_{2}\right],{ }^{22}\left[\mathrm{C}_{4} \mathrm{mmim}\right]\left[\mathrm{NTf}_{2}\right]^{22}$ and $\left[\mathrm{P}_{6,6,6,14}\right][\mathrm{OH}]^{21}$ were synthesized according to literature procedures.

\section{Synthesis of [C $\left.\mathrm{C}_{4} \mathrm{mmim}\right]\left[\mathrm{NTf}_{2}\right]$ and $\left[\mathrm{P}_{6,6,6,14]}[\mathrm{OH}]\right.$ containing gels $\mathrm{G} 1, \mathrm{G} 2$ and $\mathrm{G3}$}

Three ratios of $\left[\mathrm{P}_{6,6,6,14}\right][\mathrm{OH}]$ and $\left[\mathrm{C}_{4} \mathrm{mmim}\right]\left[\mathrm{NTf}_{2}\right]$ (see Table S5) were mixed in a small sample vial, followed by the addition of TEOS $(1.0 \mathrm{~mL})$. The samples were stirred for 20 minutes, the magnetic stirrer bars were removed, and the mixtures left to gel (samples gelled within 16 hours). After ageing for 4 weeks, the gels were washed in refluxing ethanol $(50 \mathrm{~mL} \times 3)$ for 2 hours.

\section{HTID of 1,3-PDO using mixed [ $\left.\mathrm{C}_{4} \mathrm{mmim}_{[}\right]\left[\mathrm{NTf}_{2}\right] /\left[\mathrm{P}_{6,6,6,14]}[\mathrm{OH}] \mathrm{SiO}_{2}\right.$ gels}

HTID reactions were performed by a modification of the procedure detailed in our literature. ${ }^{9,10}$

1,3-Propanediol (1.25 g, $0.0164 \mathrm{~mol}), \mathbf{C 2}(0.135 \mathrm{~g}, 0.236 \mathrm{mmol}),\left[\mathrm{P}_{6,6,6,14}\right][\mathrm{OH}] \mathrm{SiO}_{2}$ gel G1, G2 or G3 (for quantities see Table S6), and [ $\left.\mathrm{C}_{2} \mathrm{mmim}\right]\left[\mathrm{NTf}_{2}\right](2.9 \mathrm{~g}, 0.0071$ $\mathrm{mol}$ ) were mixed in a $50 \mathrm{~mL}$ round bottom flask connected, through a distillation condenser, to a $50 \mathrm{~mL}$ glass tube. The mixture was maintained at $150{ }^{\circ} \mathrm{C}$, at a controlled pressure of $c a$. 0.350 bar, for six hours, stirring at 1000 RPM using a hot plate and magnetic stirrer bar. The reaction product, a colourless liquid, was isolated by distillation, it was collected for the duration of the six hours reaction, in a glass collecting tube kept at $c a .-196^{\circ} \mathrm{C}\left(\mathrm{N}_{2(1)}\right.$ bath). After separation from the water layer, the crude product was analysed by GC/MS and ${ }^{1} \mathrm{H}$ NMR spectroscopies.

The amount of 1-propanol (5) in the isolated crude product was calculated via GC/MS spectroscopy; then integration of the ${ }^{1} \mathrm{H}$ NMR spectrum was used to calculate the molar amounts of propanal (2), 2-methyl-2-pentenal (3), and 2-methyl-pentanal (4), relative to $\mathbf{5}$.

The recycling reactions were carried out as follows. Another aliquot of 1,3-PDO was added to the reaction mixture resulting from the previous recycling experiment in the $10 \mathrm{~mL}$ round bottomed flask (full experimental details in Tables S7-9). The resulting mixture was reacted and analysed in the same way as the first reaction. 


\section{Conclusions}

Cp*Ir(III)NHC hydrogen borrowing catalyst $\mathbf{C 2}$ has been applied to the catalytic dehydration of 1,3-PDO promoted by Basic Ionic Liquid silica Gels containing a mixture of basic and hydrophobic ionic liquids. Operating the reaction in an ionic liquid solvent under vacuum enabled the isolation of the reaction products without extraction. The activities and selectivities towards propanal achievable rivalled, and the recycling outperformed the use of conventional bases. Basic binary ionic liquid gel G3 was found to support the recycling of the catalytic system without intermediate treatment nor addition of further base.

\section{Supporting Information}

Details of gel syntheses, TGA and BET data, catalytic experiments and analysis methods.

\section{Acknowledgement}

This work was supported by GRAIL (Grant agreement no: 613667), project cofinanced by the European Commission under the $7^{\text {th }}$ Framework Programme. The assistance provided by The School of Chemistry and Chemical Engineering, Queen's University Ionic Liquid Laboratories (QUILL), the analytical chemistry service (ASEP) and the glassblowing service at The Queen's University of Belfast, are acknowledged.

\section{References}

1. Grigg, R.; Mitchell, T. R. B.; Sutthivaiyakit, S.; Tongpenyai, N. Transition metalcatalysed N-alkylation of amines by alcohols, J. Chem. Soc., Chem. Commun., 1981, 611-612, DOI:10.1039/C39810000611

2. Watanabe, Y.; Tsuji, Y; Ohsugi Y. The ruthenium catalyzed N-alkylation and Nheterocyclization of aniline using alcohols and aldehydes, Tetrahedron Lett., 1981, 22, 2667-2670, DOI: 10.1016/S0040-4039(01)92965-X

3. Haniti, M.; Hamid, S. A.; Slatford, P. A.; Williams J. M. J. Borrowing Hydrogen in the Activation of Alcohols, Adv. Synth. Catal. 2007, 349, 1555-1575, DOI: 10.1002/adsc. 200600638.

4. Liu, S.; Rebros, M.; Stephens, G.; Marr, A. C., Adding value to renewables: a one pot process combining microbial cells and hydrogen transfer catalysis to utilise waste glycerol from biodiesel production. Chem. Comm. 2009, (17), 2308-2310, DOI: 10.1039/B820657K

5. Kaur, G.; Srivastava, A.; Chand, S., Advances in biotechnological production of 1, 3-propanediol. Biochem. Eng. J. 2012, 64, 106-118, DOI: 10.1016/j.bej.2012.03.002. 
6. Zeng, A.-P.; Sabra, W., Microbial production of diols as platform chemicals: recent progresses. Curr. Opin. Biotechnol. 2011, 22 (6), 749-757, DOI:

10.1016/j.copbio.2011.05.005

7. Marr, A. C. Organometallic hydrogen transfer and dehydrogenation catalysts for the conversion of bio-renewable alcohols, Catal. Sci. Technol., 2012, 2, 279-287, DOI:10.1039/C1CY00338K

8. Lacroix, S. D.; Pennycook, A.; Liu, S.; Eisenhart, T. T.; Marr, A. C. Amination and dehydration of 1,3-propanediol by hydrogen transfer: reactions of a bio-renewable platform chemical, A. C. Catal. Sci. Technol., 2012, 2, 288-290, DOI: 10.1039/C1CY00339A

9. Wang, Y-M.; Lorenzini, F.; Rebros, M.; Saunders, G. C.; Marr, A. C. Combining Bio- and Chemo-Catalysis for the Conversion of Bio-Renewable Alcohols:

Homogeneous Iridium Catalysed Hydrogen Transfer Initiated Dehydration of 1,3Propanediol to Aldehydes. Green Chem., 2016, 18, 1751-1761, DOI:

10.1039/C5GC02157J

10. Ma, Y.-Y.; Wang, Y.-M.; Morgan, P. J.; Jackson, R. E.; Liu, X.-H.; Saunders, G. C.; Lorenzini, F.; Marr, A. C. Designing effective homogeneous catalysis for glycerol valorisation: selective synthesis of a value-added aldehyde from 1,3-

propanediol via hydrogen transfer catalysed by a highly recyclable, fluorinated

Cp*Ir(NHC) catalyst, Catal. Today, 2018, 307, 248-259. DOI:

10.1016/j.cattod.2017.09.036

11. Marr, P. C.; Marr, A. C. Ionic liquid gel materials: applications in green and sustainable chemistry. Green Chem. 2017, 18, 105-128. DOI: 10.1039/C5GC02277K

12. Earle, M.J.; Seddon, K.R. Ionic liquids. Green solvents for the future. Pure Appl. Chem., 2000, 72, 1391-1398. DOI: 10.1351/pac200072071391

13. Wang, Y.-M.; Ulrich, V.; Donnelly, G. F.; Lorenzini, F.; Marr, A. C.; Marr, P. C. A Recyclable Acidic Ionic Liquid Gel Catalyst for Dehydration: Comparison with an Analogous SILP Catalyst. ACS Sustainable Chem. Eng., 2015, 3, 792-796. DOI: $10.1021 / \mathrm{sc} 5008303$.

14. Morrison, D. W.; Forbes, D. C.; Davis, J. H., Jr Base-promoted reactions in ionic liquid solvents. The Knoevenagel and Robinson annulation reactions. Tetrahedron Lett. 2001, 42, 6053-6055, DOI: 10.1016/S0040-4039(01)01228-X

15. Zhu, A.; Jiang, T.; Wang, D.; Han, B.; Liu, L.; Huang, J.; Zhang, .J; Suna, D. Direct aldol reactions catalyzed by 1,1,3,3-tetramethylguanidine lactate without solvent. Green Chem., 2005, 7, 514-517. DOI:10.1039/B501925G

16. Ranu, B. C.; Jana, R; Ionic Liquid as Catalyst and Reaction Medium - A Simple, Efficient and Green Procedure for Knoevenagel Condensation of Aliphatic and Aromatic Carbonyl Compounds Using a Task-Specific Basic Ionic Liquid. Eur. J. Org. Chem., 2006, 16, 3767-3770. DOI: 10.1002/ejoc.200600335 
17. Lombardo, M.; Easwar, S.; Pasi, F.; Trombini, C. The Ion Tag Strategy as a Route to Highly Efficient Organocatalysts for the Direct Asymmetric Aldol Reaction. Adv. Synth. Catal. 2009, 351, 276-282. DOI: 10.1002/adsc.200800608

18. Xu, D.-Z.; Liu, Y.; Shia, S.; Wang, Y. A simple, efficient and green procedure for Knoevenagel condensation catalyzed by $\left[\mathrm{C}_{4} \mathrm{dabco}\right]\left[\mathrm{BF}_{4}\right]$ ionic liquid in water. Green Chem., 2010, 12, 514-517. DOI:10.1039/B918595J

19. Stewart A. Forsyth, S. A.; Fröhlich, U.; Goodrich, P.; Gunaratne, H. Q. N.; Hardacre, C.; McKeown, A.; and Seddon, K. R. Functionalised ionic liquids: synthesis of ionic liquids with tethered basic groups and their use in Heck and Knoevenagel reactions. New J. Chem., 2010, 34, 723-731. DOI:

10.1039/B9NJ00729F

20. McNeice, P; Marr, A. C.; Marr, P. C.; Earle, M. J. and Seddon, K. R. Basic Alkoxide Ionic Liquids, ACS Sustainable Chem. Eng. 2018, 6, 11, 13676-13680. DOI: 10.1021/acssuschemeng.8b04299

21. Bothwell, K. M.; Marr, P. C. Taming the Base Catalyzed Sol-Gel Reaction: Basic Ionic Liquid Gels of $\mathrm{SiO}_{2}$ and $\mathrm{TiO}_{2}$. ACS Sustainable Chem. Eng., 2017, 5, 12601263. DOI: 10.1021/acssuschemeng.6b02772

22. Study on thermodynamic properties and estimation of polarity of ionic liquids $\left\{\left[\mathrm{C}_{n} \mathrm{mmim}\right]\left[\mathrm{NTf}_{2}\right](n=2,4)\right\}$ J. Wei, T. Ma, X. Ma, W. Guan, Q. Liu, J. Yang, RSC Adv., 4 (2014), pp. 30725-30732. DOI: 10.1039/C4RA04391J 
For Table of Contents Use Only.

\section{Synopsis.}

Ionic liquids served as the solvent and gel base to promote HTID of 1,3-propanediol to propanal with solvent-less product separation.

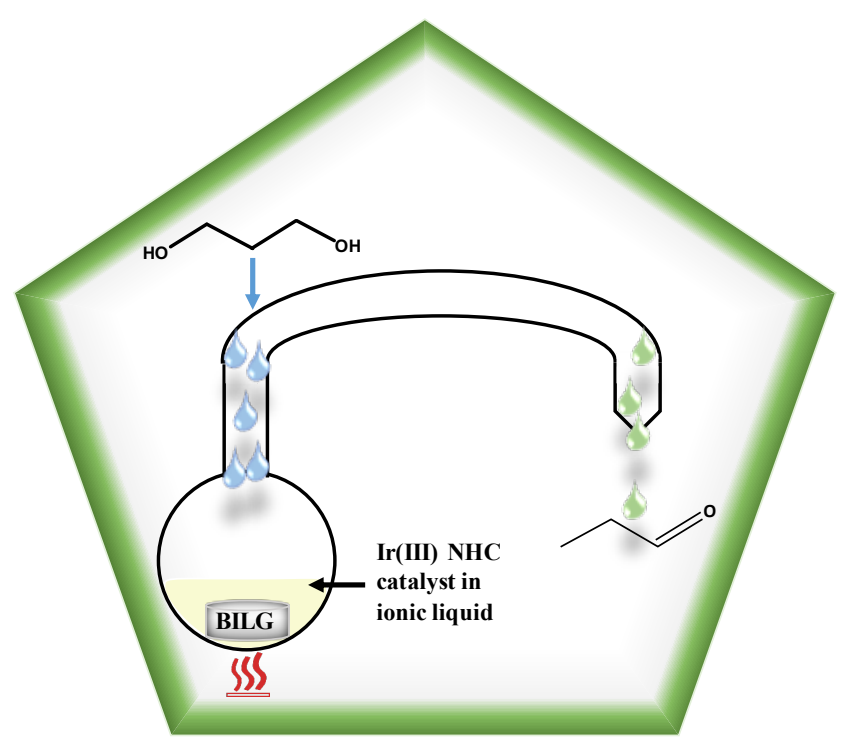

